\title{
Edward Edwards
}

Mr. E. Edwards, who died at Llandinam on 28th April, 1944, had been a member of the Society since 1905. Born at Llangedwyn on 5th May, 1870, he was educated at Oswestry High School and Bala Theological College before entering the University College of Wales, Aberystwyth. On the staff at Aberystwyth in those days was the late Dr. H. Ethé, whose contributions to the study of Persian literature are well known to all serious students of Persian. Dr. Ethé as Professor of German and Oriental Languages was prepared to teach Hebrew, Arabic, Syriac, Sanskrit, and at least two or three other languages, if students presented themselves. The Oriental language with which Edwards was best acquainted at that period was Hebrew, but under Ethé he studied also Syriac, Arabic, and Persian. He was in fact the first student to take a degree course in Persian since Ethé joined the staff of the College in 1875. When he sat for his examination the External Examiner was $\mathrm{E}$. G. Browne, who thus saw for the first time the work of his future pupil.

In October, 1900, Edwards entered Christ's College, Cambridge, and in 1903 he was placed in the Third Class of the Oriental Languages Tripos, his languages being Hebrew, Aramaic, and Arabic.

In 1904 he entered the Department of Oriental Printed Books and Manuscripts at the British Museum, in 1912 he became a First Class Assistant, and in 1935 he retired on reaching the age of superannuation.

His chief contribution to Oriental scholarship was $A$ catalogue of the Persian printed books in the British Museum, which appeared in 1922. This excellent piece of work, the first satisfactory catalogue of a large collection of Persian printed books, worthily commemorates his years of labour in the Oriental Department. An earlier publication, $A$ descriptive list of the Arabic manuscripts acquired by the Trustees of the British Museum since 1894, which appeared in 1912, was written partly by him and partly by the late A. G. Ellis. To the Volume of Oriental studies presented to Edward G. Browne on his 60th birthday (7 February, 1922) Edwards contributed an article entitled Some rare and important Arabic and Persian manuscripts from the collections of Hājoji 'Abdu'l-Majīd Belshah; now 
either in the British Museum or in the private collection of Professor Edward G. Browne.

In his later years Edwards was much afflicted with rheumatism and worked under difficulties.

\section{Colonel D. M. F. Hoysted (1874-1945)}

As his second Christian name indicates, Desmond Murree Fitzgerald Hoysted was born at Murree in the Panjab, his father, who later became Surgeon-General, Madras Presidency, Indian Army, being then stationed in India. Educated at Rugby School and the Royal Military Academy, he was appointed to the Royal Engineers, and promoted in 1894 Lieutenant in the 26th Field Company, R.E. Serving throughout the South African War of 1899-1902, he took part in, amongst others, the engagements at Coleskop, Colesberg, Modder River, Paardeburg, Bloemfontein, Abraham's Kraal, Nicholson's Nek, the capture of Pretoria, and Vereiniging, receiving the Queen's Medal with three clasps and the King's Medal with two clasps. Returning home from Natal in 1904 he served on the Staff as Division Officer, R.E., and acting C.R.E. Dublin District. He was then posted to the Alexandria Garrison of the British Army of Occupation in Egypt, where he served until 1914, when he was appointed Staff Officer, London District. It was during this long service in Egypt that he acquired a taste for Oriental subjects. On the outbreak of World War I he went to France, and was the second man of the B.E.F. to land at Le Havre on 6th August, 1914. In command of the 9th Field Company R.E. he fought on the Marne and the Aisne, at Armentières, Ploegsteert Wood, and the Ypres Salient, receiving the 1914 (Mons) Star. In September, 1915, he was appointed C.R.E. 22nd Infantry Division, Serbian Expeditionary Force, and took part in the actions at Salonika, the Struma Valley, and Lake Doiran, and in Bulgaria, being mentioned in dispatches on three occasions, and being awarded the D.S.O. for special service in 1916. In 1917 he was invalided home, but was able to carry on the duties of Chief Instructor of Fortifications until 1918, when he returned to France as C.R.E. 3rd Army Defence Lines, B.E.F. After the war he held the appointments of Instructor, Senior Officers' School, Woking, and of C.R.E. 